\title{
Nicotinamide-N-Methyltransferase gene rs694539 variant and migraine risk
}

\author{
Ali Sazci ${ }^{1 *}$, Gensay Sazci ${ }^{1}$, Bilgen Sazci ${ }^{1}$ Emel Ergul ${ }^{1}$ and Halil Atilla Idrisoglu ${ }^{2}$
}

\begin{abstract}
Background: Migraine is a common neurovascular disorder affecting 10 to $20 \%$ of the world population usually subdivided into migraine with auro (MA) and migraine without auro (MO). Homocysteine is involved in the pathophysiology of a number of neurological disorders. Elevated levels of homocysteine in the plasma is produced by the MTHFR gene rs 1801133 and rs 1801131 variants as well as the NNMT gene rs 694539 variant.

Methods: With the polymerase chain reaction-restriction fragment length polymorphism method developed recently in our laboratory, we were able to show an association between the NNMT gene rs694539 variant and migraine for the first time.

Results: Here we report the association of the Nicotinamide-N-methyltransferase gene (NNMT) rs694539 variant with migraine in a case-control study of 433 patients with migraine and 229 healthy controls $(x 2=6.076, P=0$. 048). After stratification, we were able only to show an association between the NNMT gene rs694539 variant and female patients with migraine on the genotype and allelic levels. However there was no association in male patients with migraine $(X 2=1.054, P=0.590)$.

Conclusions: Consequently our results clearly indicate that the NNMT gene rs694539 variant is a genetic risk factor for migraine.
\end{abstract}

Keywords: NNMT gene, Association, rs694539, One carbon metabolism, Gender association, Turkey

\section{Background}

Migraine is a common and chronic neurovascular disorder affecting approximately $10-20 \%$ of the world population. Clinically, It is sub-classified into migraine with aura (MA) and migraine without aura (MO) accompanied by severe recurrent headache attacks and associated symptoms such as nausea, vomiting, photo- and phonophobia [1].

Homocysteine, a sulfur-containing amino acid derived from the metabolism of methionine, has been implicated in the pathophysiology of a variety of neurological disorders such as migraine [1], essential tremor [2], stroke [3], epilepsy [4]), schizophrenia [5, 6] and bipolar disorders [7, 8]. 5,10-Methylenetetrahydrofolate reductase (MTHFR), a key enzyme in the metabolism of folate catalyzes the reduction of 5,10-methylenetetrahydrofolate to 5-methyltetrahydrofolate, the predominant form of folate and carbon donor for the remethylation of

\footnotetext{
*Correspondence: alisazci@gmail.com

'Department of Medical Biology and Genetics, Faculty of Medicine,

University of Kocaeli, Kocaeli 41380, Turkey

Full list of author information is available at the end of the article
}

homocysteine to metionine. Variants of the MTHFR C677T (rs1801133) and A1298C (rs1801131) gene, associated with significantly elevated plasma homocysteine levels, were shown to be associated with migraine [9-21]. A meta-analysis has revealed that the MTHFR C677T (rs1801133) variant is a genetic risk factor for migraine [22]. Another enzyme implicated in one-carbon metabolism is nicotinamide-N-methyltransferase (NNMT). Human NNMT (EC 2.1.1.1), a cytoplasmic enzyme belonging to Phase II conjugating enzymes, is reported to be expressed in brain and other nervous tissues [23]. This gene is $16.703 \mathrm{bp}$ in lenght on chromosome 11q23.1, having three exons and two introns. NNMT catalyzes the transfer of methyl group from S-adenosyl-L-methionine (SAM) to nicotinamide (NA), thus creating 1-methylnicotinamide (1MNA) and S-adenosylhomocysteine (SAH) which is later hydrolyzed to homocysteine [24]. Homocysteine is one of the key components of one-carbon metabolism. The rs694539 NNMT variant, localized at the 114133419 bp ( $\mathrm{G}>\mathrm{A}$ transition) is found to be significanly associated with 
elevated plasma homocysteine levels [25]. Elevated plasma homocysteine levels were shown to be associated with an increased risk of migraine in patients with the MTHFR C677T and A1298C polymorphisms [1, 11].

Recently, we showed that the MTHFR C677T and A1298C variants were associated with migraine [1]. We also wanted to reveal whether the rs694539 variant of NNMT gene is associated with migraine. To do so we analyzed the allele and genotype frequencies of the NNMT gene rs694539 variant in 433 patients with migraine and 229 healthy controls.

\section{Methods}

\section{Subjects}

The subjects were 433 [351 (81\%) female; 82 (19\%) male] patients with migraine and 229 [184 (80\%) female; 45 (20\%) male] healthy controls recruited from the Istanbul University neurological clinic. The mean age of migraine was $36.96 \pm 14.863$ years and controls was $37.54 \pm 16.403$ years; age range for cases was $18-89$ years, and for controls was 19-85 years. All patients were diagnosed by an experienced neurologist using International Classification of Headache Disorders (ICHD) the third version (2013) [26]. The institutional review board approved the present study and informed consent was obtained from all subjects.

\section{Genotyping}

Genomic DNA was isolated from whole blood using the salting-out procedure [27]. Genotypes of the subjects were determined using a polymerase chain reactionrestriction fragment length polymorphism (PCR-RFLP) method developed in our laboratory [28].

\section{Statistical analysis}

The Hardy-Weinberg equilibrium was verified for both cases and controls. Differences between cases and controls were determined using the $\chi 2$ test and Student's $t$ test. Genotype and allele frequencies were calculated using the $\chi 2$ test. Odds ratio (OR) and confidence interval $(95 \% \mathrm{CI})$ were estimated using $2 \times 2$ cross-tabulation and a binary logistic regression model for age and gender. All statistical analyses were done using SPSS software package version 21.0. The $P$ value $<0.05 \%$ was taken as significant.

\section{Results and discussion}

Here, we report an association between the rs694539 variant of NNMT gene with migraine for the first time $(\chi 2=$ $6.076, P=0.048$ ). The statistical power for all cases is 0.40 and for overall controls is 0.24 (Table 1 ). The individuals with AA genotype confer a 3.8-fold increased risk for migraine $(\chi 2=5.372, P=0.020$, OR $=3.840,95 \% \mathrm{CI}=1.133$ 13.013). Moreover, the $G$ allele showed a 3.8 -fold protection against migraine $(\chi 2=5.372, P=0.020, \mathrm{OR}=$ $0.260,95 \% \mathrm{CI}=0.077-0.883)$. Stratification analysis according to gender revealed that there was an association only in female patients with migraine. The female individuals with the AA genotype revealed a 4.3-fold increased risk for migraine $(\chi 2=4.474, P=0.034$, OR $=4.346,95 \%$ $\mathrm{CI}=0.988-19.112$ ). Similarly the individuals with the $G$ allele showed a 4.3-fold protection against migraine $(\mathrm{X}=$ 4.474, $P=0.034, \quad \mathrm{OR}=0.230,95 \% \mathrm{CI}=0.052-1.012$ ). However there was no association in male patients with migraine $(\chi 2=1.054, P=0.590)$. All patients with migraine and controls were in Hardy-Weinberg equilibrium (0.665 and 0.152 , respectively) (Table 1 ).

Distributions of genotypes GG, GA and AA were 62.6, 32.6 and $4.8 \%$ in overall patients with migraine and 68.1, 30.6 and $1.3 \%$ in overall controls respectively (Table 1 ). The frequencies of $\mathrm{G}$ allele were $78.87 \%$ in overall cases and $83.40 \%$ in overall controls (Table 1). The frequencies of A allele were $21.13 \%$ in overall migraine patients and $16.59 \%$ in overall controls (Table 1).

In the case control studies, a number of polymorphisms have been shown to be associated with migraine. Plasma urotensin-2 level and thr21met variant have been reported to be associated with migraine [29]. It has been also shown that the glutamatergic system is involved in the pathophysiology of migraine [30]. DNA methylation status of RAMP1 gene has been shown to be associated with migraine [31]. Rs4379368 in the C7orf10 gene and rs13208321 in the FHL 5 gene have been reported to be associated with migraine [32]. Genetic variants in the SYNE1 and TNF genes have been shown to be related to menstrual migraine [33].

Recently genome-wide association studies have implicated neuronal, vascular, metalloproteinase and pain pathways in migraine [34].

More recently, GWASs have identified several single nucleotide polymorphisms associated with migraine pathophysiology [35-37] in genes and in regulatory regions of genes implicated in epigenetic processes, including MTDH, MEF2D and PRDM16. Metadherin (MTDH) is shown to be associated with nuclear factor B (NFB) and a HAT to promote the expression of NFB target genes [38]. Myocyte enhancer factor 2D (MEF2D) can target methyltransferase complexes to specific genes to make them available for gene expression [39]. MEF2 has recently been shown to be modulated through the glucocorticoid receptor [40], which may be one of the mechanisms by which stress hormones affect the epigenome. Finally, PR domain containing 16 (PRDM16) is implicated in positioning and removing specific chromatin modifications at enhancer regions of Notch target genes during olfactory neuron differentiation [41]. These studies indicate that some of the migraine GWAS hits may contribute to developing migraine through epigenetic alterations at their target genes [42]. 
Table 1 Genotype and Allele frequencies of the NNMT gene rs694539 variant in patients with Migraine and controls

\begin{tabular}{|c|c|c|c|c|c|}
\hline Gene & Cases & Controls & $x^{2}$ & $P$-Values & OR; $95 \% \mathrm{Cl}$ \\
\hline NNMT Rs694539 & $433(100.0)$ & $229(100.0)$ & 6.076 & 0.048 & \\
\hline GG & $271(62.6)$ & $156(68.1)$ & 2.005 & 0.157 & $0.783(0.558-1.099)$ \\
\hline GA & $141(32.6)$ & $70(30.6)$ & 0.275 & 0.600 & $1.097(0.776-1.550)$ \\
\hline AA & $21(4.8)$ & $3(1.3)$ & 5.372 & 0.020 & $3.840(1.133-13.013)$ \\
\hline \multicolumn{6}{|l|}{ Allele frequency } \\
\hline G Allele & $683(78.87)$ & $382(83.40)$ & 5.372 & 0.020 & $0.260(0.077-0.883)$ \\
\hline A Allele & $183(21.13)$ & $76(16.59)$ & 2.005 & 0.157 & 1.277 (0.910-1.794) \\
\hline HWE(exact) & 0.665 & 0.152 & & & \\
\hline Statistical power & 0.40 & 0.24 & & & \\
\hline Gene & $\begin{array}{l}\text { Cases } \\
\text { Female }\end{array}$ & $\begin{array}{l}\text { Controls } \\
\text { Female }\end{array}$ & $x^{2}$ & P-Values & OR; $95 \% \mathrm{Cl}$ \\
\hline NNMT rs694539 & $351(100.0)$ & $184(100.0)$ & 5.650 & 0.059 & \\
\hline GG & $220(62.7)$ & $128(69.6)$ & 2.518 & 0.113 & $0.735(0.502-1.076)$ \\
\hline GA & 115 (32.8) & $54(29.3)$ & 0.652 & 0.419 & $1.173(0.796-1.729)$ \\
\hline AA & $16(4.6)$ & $2(1.1)$ & 4.474 & 0.034 & $4.346(0.988-19.112)$ \\
\hline \multicolumn{6}{|l|}{ Allele frequency } \\
\hline G Allele & $555(79.06)$ & $310(84.24)$ & 4.474 & 0.034 & $0.230(0.052-1.012)$ \\
\hline A Allele & $147(20.94)$ & $58(15.76)$ & 2518 & 0.113 & 1.361 (0.930-1.993) \\
\hline HWE(exact) & 0.872 & 0.262 & & & \\
\hline Statistical power & 0.43 & 0.25 & & & \\
\hline Gene & $\begin{array}{l}\text { Cases } \\
\text { Male }\end{array}$ & $\begin{array}{l}\text { Controls } \\
\text { Male }\end{array}$ & $x^{2}$ & P-Values & OR; $95 \% \mathrm{Cl}$ \\
\hline NNMT rs694539 & $82(100.0)$ & $45(100.0)$ & 1.054 & 0.590 & \\
\hline GG & $51(62.2)$ & $28(62.2)$ & 0.000 & 0.998 & $0.999(0.472-2.114)$ \\
\hline GA & $26(31.7)$ & $16(35.6)$ & 0.194 & 0.659 & $0.842(0.391-1.813)$ \\
\hline $\mathrm{AA}$ & $5(6.1)$ & $1(2.2)$ & 0.969 & 0.325 & $2.857(0.323-25.244)$ \\
\hline \multicolumn{6}{|l|}{ Allele frequency } \\
\hline G Allele & $128(78.05)$ & $72(80.00)$ & 0.969 & 0.325 & $0.350(0.040-3.092)$ \\
\hline A allele & $36(21.95)$ & $18(20.00)$ & 0.000 & 0.998 & $1.001(0.473-2.119)$ \\
\hline HWE(exact) & 0.520 & 0.665 & & & \\
\hline Statistical power & 0.05 & 0.04 & & & \\
\hline
\end{tabular}

HWE Hardy-Weinberg Equilibrium

Two GWAS have been carried out in migraine. One of which concentrated mainly on patients with migraine with auro and identified a single SNP in the MTDH gene [34]. The other study concentrated on migraine without auro and identified six SNPs in the MEF2D, TGFBR2, PHACTR1, ASTN2, TRPM8, and LRP1 gene associated with migraine [37]. Recently a meta-analysis of studies on migraine identified 12 SNPs significantly associated with migraine [42]. Thus far 13 migraine susceptibility loci identified are associated with neuronal (MTDH, LRP1, PRDM16, MEF2D, ASTN2, PHACTR1, FHL5, MMP16), vascular (PHACTR1, TGFBR2, c7orf10), metalloproteinase (MMP16, TSPAN2, AJAP1) and pain (TRPM8) pathways. Most recently, GWAS using 59674 migraine cases and 316078 controls identified
45 independent migraine associated SNPs mapping to 38 distinct genomic regions, 28 of which have not been previously reported [43].

However, global DNA methylation has not been reported in patients with migraine, elevated homocysteine levels were revealed to be associated with cognitive impairment $[44,45]$.

\section{Conclusions}

In summary, the role of the rs694539 variant of the NNMT gene in migraine is unclear. Nonetheless, through dysregulation of epigenetics and/or elevated homocysteine levels or dysregulation of nicotinamide levels may result in migraine or particularly through 
vascular processes. Thus, our findings suggest that the rs694539 variant of NNMT gene may play a role in the etiopathology of migraine in the Turkish population studied herein.

\section{Authors' contributions}

$A S, G S, B S$. EE and HAI were involved in conception and design of the study. $\mathrm{GS}, \mathrm{BS} ; \mathrm{EE}, \mathrm{AS}$ and HAl did the experiments and analyzed the data statistically. The manuscript was drafted by AS with input from EE and HAI. All authors reviewed and approved the final manuscript.

\section{Competing interests}

The authors declare that they have no competing interests.

\section{Author details}

'Department of Medical Biology and Genetics, Faculty of Medicine, University of Kocaeli, Kocaeli 41380, Turkey. ${ }^{2}$ Department of Neurology, Istanbul Faculty of Medicine, University of Istanbul, Istanbul, Capa 34290, Turkey.

\section{Received: 27 August 2016 Accepted: 6 October 2016}

\section{Published online: 10 October 2016}

\section{References}

1. Kara I, Sazci A, Ergul E, Kaya G, Kilic G (2003) Association of the C677T and A1298C polymorphisms in the 5,10 methylenetetrahydrofolate reductase gene in patients with migraine risk. Mol Brain Res 111(1-2):84-90

2. Sazci A, Ergul E, Bayulkem K (2004) Association of the C677T and A1298C polymorphisms of methylenetetrahydrofolate reductase gene in patients with essential tremor in Turkey. Mov Disord 19(12):1472-1476

3. Sazci A, Ergul E, Tuncer N, Akpinar G, Kara I (2006) Methylenetetrahydrofolate reductase gene polymorphisms are associated with ischemic and hemorrhagic stroke: Dual effect of MTHFR polymorphisms C677T and A1298C. Brain Res Bull 71(1-3):45-50

4. Sazci G, Sazci B, Sazci A, Idrisoglu HA (2016) Association of Nicotinamide-NMethyltransferase Gene rs694539 Variant with Epilepsy. Mol Neurobiol. 53(6): 4197-4200. doi:10.1007/s12035-015-9364-2.

5. Sazci A, Ergül E, Güzelhan Y, Kaya G, Kara I (2003) Methylenetetrahydrofolate reductase gene polymorphisms in patients with schizophrenia. Mol Brain Res 117(1):104-107

6. Sazci A, Ergul E, Kucukali I, Kara I, Kaya G (2005) Association of the C677T and $\mathrm{A} 1298 \mathrm{C}$ polymorphisms of methylenetetrahydrofolate reductase gene with schizophrenia: association is significant in men but not in women. Prog Neuropsychopharmacol Biol Psychiatry 29(7):1113-1123

7. Ozbek Z, Kucukali Cl, Ozkok E, Orhan N, Aydin M, Kilic G, Sazci A, Kara I (2008) Effect of the methylenetetrahydrofolate reductase gene polymorphisms on homocysteine, folate and vitamin B12 in patients with bipolar disorder and relatives.Prog. Neuropsychopharmacol Biol Psychiatry 32(5):1331-1337

8. Sazci A, Ozel MD, Ergul E, Onder ME (2013) Association of nicotinamide-Nmethyltransferase (NNMT) gene rs694539 variant with bipolar disorder. Gene 532(2):272-275

9. Frosst P, Blom HJ, Milos R, Goyette P, Sheppard CA, Matthews RG, Boers GJ, den Heijer M, Kluijtmans LA, van den Heuvel LP, Rozen R (1995) A candidate genetic risk factor for vascular disease: a common mutation in methylenetetrahydrofolate reductase. Nat Genet 10(1):111-113

10. Weisberg I, Tran P, Christensen B, Sibani S, Rozen R (1998) A second genetic polymorphism in methylenetetrahydrofolate reductase (MTHFR) associated with decreased enzyme activity. Mol Genet Metab 64(3):169-172

11. Kowa H, Yasui K, Takeshima T, Urakami K, Sakai F, Nakashima K (2000) The homozygous C677T mutation in the methylenetetrahydro-folate reductase gene is a genetic risk factor for migraine. Neuro-psychiatric Genet 96:762-764

12. Lea RA, Ovcaric M, Sundholm J, MacMillan J, Griffiths LR (2004) The methylenetetrahydrofolate reductase gene variant C677T influences susceptibility to migraine with aura. BMC Med 2(1):3

13. Lea RA, Ovcaric M, Sundholm J, Solyom L, Macmillan J, Griffiths LR (2005) Genetic variants of angiotensin converting enzyme and methylenetetrahydrofolate reductase may act in combination to increase migraine susceptibility.Mol. Brain Res 136(1-2):112-117

14. Oterino A, Valle N, Pascual J, Bravo Y, Muñoz P, Castillo J, Ruiz-Alegría C, Sánchez-Velasco P, Leyva-Cobián F, Cid C (2005) Thymidylate synthase promoter tandem repeat and MTHFD1 R653Q polymorphisms modulate the risk for migraine conferred by the MTHFR T677 allele. Mol Brain Res 139(1):163-168

15. Scher Al, Terwindt GM, Verschuren WM, Kruit MC, Blom HJ, Kowa H, Frants $R R$, van den Maagdenberg AM, van Buchem M, Ferrari MD, Launer LJ (2006) Migraine and MTHFR C677T genotype in a population-based sample. Ann Neurol 59(2):372-375

16. Pezzini A, Grassi M, Del Zotto E, Giossi A, Monaste ro R, Dalla Volta G, Archetti S, Zavarise P, Camarda C, Gasparotti R (2007) Migraine mediates the influence of C677T MTHFR genotypes on ischemic stroke risk with a stroke-subtype effect. Stroke 38(12):3145-3151

17. Schurks M, Zee RY, Buring JE, Kurth T (2008) Interrelationships among the MTHFR 677C T polymorphism, migraine, and cardiovascular disease. Neurology 71(7):505-513

18. Tietjen G, Herial N, Utley C, White L, Yerga-Woolwine S, Joe B (2009) Association of von Willebrand factor activity with ACE I/D and MTHFR C677T polymorphisms in migraine. Cephalalgia 29(9):960-968

19. Azimova JE, Sergeev AV, Korobeynikova LA, Kondratieva NS, Kokaeva ZG, Shaikhaev GO, Skorobogatykh KV, Fokina NM, Tabeeva GR, Klimov EA (2013) Effects of MTHFR gene 1325 polymorphism on the clinical and electrophysiological characteristics of migraine. BMC Neurol 13(1):103

20. An X-K, Lu C-X, Ma Q-L, Zhang X-R, Burgunder J-M, Lin Q, Qu H-L (2013) Association of MTHFR C677T polymorphism with susceptibility to migraine in the Chinese population. Neurosci Lett 549:78-81

21. Liu A, Menon S, Colson NJ, Quinlan S, Cox H, Peterson M, Tiang T, Haupt LM, Lea RA, Griffiths LR (2010) Analysis of the MTHFR 2018 C677T variant with migraine phenotypes. BMC Res Notes 3(1):213

22. Liu R, Geng P, Ma M, Yu S, Yang M, He M, Dong Z, Zhang W (2014) MTHFR C677T polymorphism and migraine risk: a meta-analysis. J Neurol Sci 336(1-2): 68-73

23. Sano A, Endo N, Takitani S (1992) Fluorometric assay of rat tissue Nmethyltransferases with nicotinamide and four isomeric methylnicotinamides. Chem Pharm Bull (Tokyo) 40:153-156

24. Aksoy S, Szumlanski CL, Weinshilboum RM (1994) Human liver nicotinamideNmethyltransferase. cDNA cloning, expression, and biochemical characterization. J Biol Chem 269:14835-14840

25. Souto JC, Blanco-Vaca F, Soria JM, Buil A, Almasy L, Ordoñez-Llanos J, MartínCampos JM, Lathrop M, Stone W, Blangero J, Fontcuberta J (2005) A genomewide exploration suggests a new candidate gene at chromosome $11 \mathrm{q} 23$ as the major determinant of plasma homocysteine levels: results from the GAIT project. Am J Hum Genet 76(6):925-933

26. Headache Classification Committee of the International Headache Society (2013) The international classification of headache disorders, 3rd edition. Cephalalgia 33:629-808, beta version

27. Miller SA, Dykes DD, Polesky HF (1988) A simple salting out procedure for extracting DNA from human nucleated cells. Nucleic Acids Res 16(3):1215

28. Sazci A, Ozel MD, Ergul E, Aygun C (2013) Association of nicotinamide-Nmethyltransferase gene rs694539 variant with patients with nonalcoholic steatohepatitis. Genet Test Mol Biomarkers 17(11):849-853

29. Geyik S, Ergun S, Kuzudişli S, Şensoy F, Temiz E, Altunışık E, Korkmaz M, Dağlı H, Kul S, Akçalı A, Neyal AM (2016) Plasma urotensin-2 level and Thr21Met but not Ser89Asn polymorphisms of the urotensin-2 gene are associated with migraines. J Headache Pain 17:36-43

30. Fang J, An X, Chen S, Yu Z, Ma Q, Qu H (2015) Case-control study of GRIA1 and GRIA3 gene variants in migraine. J Headache Pain 17:2-7

31. Wan D, Hou L, Zhang X, Han X, Chen M, Tang W, Liu R, Dong Z, Yu S (2015) DNA methylation of RAMP1 gene in migraine: an exploratory analysis. J Headache Pain 16:90-95

32. Lin $Q F$, Fu XG, Yao LT, Yang J, Cao LY, Xin YT, Hou JX, Ye LF, Huang GB (2015) Association of genetic loci for migraine susceptibility in the she people of China. J Headache Pain 16:553-559

33. Rodriguez-Acevedo AJ, Smith RA, Roy B, Sutherland H, Lea RA, Frith A, MacGregor EA, Griffiths LR (2014) Genetic association and gene expression studies suggest that genetic variants in the SYNE1 and TNF genes are related to menstrual migraine. J Headache Pain 15:62. doi:10.1186/1129-2377-15-62

34. Nyholt DR, van den Maagdenberg AM (2016) Genome-wide association studies in migraine: current state and route to follow. Curr Opin Neurol 29(3):302-308

35. Anttila V, Stefansson H, Kallela M, Todt U, Terwindt GM, Calafato MS, Nyholt DR, Dimas AS, Freilinger T, Müller-Myhsok B, Artto V, Inouye M, Alakurtti K, Kaunisto MA, Hämäläinen $E$, de Vries B, Stam AH, Weller CM, Heinze A, 
Heinze-Kuhn K, Goebel I, Borck G, Göbel H, Steinberg S, Wolf C, Björnsson A, Gudmundsson G, Kirchmann M, Hauge A, Werge T, Schoenen J, Eriksson JG, Hagen K, Stovner L, Wichmann HE, Meitinger T, Alexander M, Moebus S, Schreiber S, Aulchenko YS, Breteler MM, Uitterlinden AG, Hofman A, van Duijn CM, Tikka-Kleemola P, Vepsäläinen S, Lucae S, Tozzi F, Muglia P, Barrett J, Kaprio J, Färkkilä M, Peltonen L, Stefansson K, Zwart JA, Ferrari MD, Olesen J, Daly M, Wessman M, van den Maagdenberg AM, Dichgans M, Kubisch C, Dermitzakis ET, Frants RR, Palotie A, International Headache Genetics Consortium (2010) Genome-wide association study of migraine implicates a common susceptibility variant on 8q22.1. Nat Genet 42(10):869-873

36. Chasman DI, Schurks M, Anttila V, de Vries B, Schminke U, Launer LJ, Terwindt GM, van den Maagdenberg AM, Fendrich $\mathrm{K}$, Volzke H, Ernst F, Griffiths LR, Buring JE, Kallela M, Freilinger T, Kubisch C, Ridker PM, Palotie A, Ferrari MD, Hoffmann W, Zee RY, Kurth T (2011) Genome-wide association study reveals three susceptibility loci for common migraine in the general population. Nat Genet 43:695-698

37. Freilinger $T$, Anttila V, de Vries B, Malik R, Kallela M, Terwindt GM, PozoRosich P, Winsvold B, Nyholt DR, van Oosterhout WP, Artto V, Todt U, Hamalainen E, Fernandez-Morales J, Louter MA, Kaunisto MA, Schoenen J, Raitakari O, Lehtimaki T, Vila-Pueyo M, Gobel H, Wichmann E, Sintas C, Uitterlinden AG, Hofman A, Rivadeneira F, Heinze A, Tronvik E, van Duijn CM, Kaprio J, Cormand B, Wessman M, Frants RR, Meitinger T, MüllerMyhsok B, Zwart JA, Farkkila M, Macaya M, Ferrari MD, Kubisch C, Palotie A, Dichgans M, van den Maagdenberg AM, International Headache Genetics Consortium (2012) Genome-wide association analysis identifies susceptibility loci for migraine without aura. Nat Genet 44:777-782

38. Sarkar D, Park ES, Emdad L, Lee SG, Su ZZ, Fisher PB (2008) Molecular basis of nuclear factor-kappaB activation by astrocyte elevated gene-1. Cancer Res 68:1478-1484

39. Rampalli S, Li L, Mak E, Ge K, Brand M, Tapscott SJ, Dilworth FJ (2007) p38 MAPK signaling regulates recruitment of Ash2L-containing methyltransferase complexes to specific genes during differentiation. Nat Struct Mol Biol 14:1150-1156

40. Speksnijder N, Christensen KV, Didriksen M, De Kloet ER, Datson NA (2012) Glucocorticoid receptor and myocyte enhancer factor 2 cooperate to regulate the expression of c-Jun in a neuronal context. J Mol Neurosci 48:209-218

41. Endo K, Karim MR, Taniguchi H, Krejci A, Kinameri E, Siebert M, Ito K, Bray SJ, Moore AW (2012) Chromatin modification of Notch targets in olfactory receptor neuron diversification. Nat Neurosci 15:224-233

42. Eising E, Datson NA, van den Maagdenberg AM, Ferrari MD (2013) Epigenetic mechanisms in migraine: a promising avenue? BMC Med 11:26

43. Anttila V, Winsvold BS, Gormley P, Kurth T, Bettella F, McMahon G, Kallela M, Malik R, de Vries B, Terwindt G, Medland SE, Todt U, McArdle WL, Quaye L, Koiranen M, Ikram MA, Lehtimäki T, Stam AH, Ligthart L, Wedenoja J, Dunham I, Neale BM, Palta P, Hamalainen E, Schürks M, Rose LM, Buring JE, Ridker PM, Steinberg S, Stefansson H, Jakobsson F, Lawlor DA, Evans DM, Ring SM, Färkkilä M, Artto V, Kaunisto MA, Freilinger T, Schoenen J, Frants RR, Pelzer N, Weller CM, Zielman R, Heath AC, Madden PA, Montgomery GW, Martin NG, Borck G, Göbel H, Heinze A, Heinze-Kuhn K, Williams FM, Hartikainen AL, Pouta A, van den Ende J, Uitterlinden AG, Hofman A, Amin N, Hottenga JJ, Vink JM, Heikkilä K, Alexander M, Muller-Myhsok B, Schreiber S, Meitinger T, Wichmann HE, Aromaa A, Eriksson JG, Traynor BJ, Trabzuni D, Rossin E, Lage K, Jacobs SB, Gibbs JR, Birney E, Kaprio J, Penninx BW, Boomsma DI, van Duijn C, Raitakari O, Jarvelin MR, Zwart JA, Cherkas L, Strachan DP, Kubisch C, Ferrari MD, van den Maagdenberg AM, Dichgans M, Wessman M, Smith GD, Stefansson K, Daly MJ, Nyholt DR, Chasman DI, Palotie A, North American Brain Expression Consortium, UK Brain Expression Consortium, International Headache Genetics Consortium (2013) Genome-wide meta-analysis identifies new susceptibility loci for migraine. Nat Genet 45(8):912-917

44. Osher Y, Sela BA, Levine J, Belmaker RH (2004) Elevated homocysteine levels in euthymic bipolar disorder patients showing functional deterioration. Bipolar Disord 6(1):82-86

45. Dittmann S, Hennig-Fast K, Gerber S, Seemüller F, Riedel M, Emanuel Severus W, Langosch J, Engel RR, Möller HJ, Grunze HC (2008) Cognitive functioning in euthymic bipolar I and bipolar I| patients. Bipolar Disord 10(8):877-887

\section{Submit your manuscript to a SpringerOpen ${ }^{\circ}$ journal and benefit from:}

- Convenient online submission

- Rigorous peer review

- Immediate publication on acceptance

- Open access: articles freely available online

- High visibility within the field

- Retaining the copyright to your article

Submit your next manuscript at $\boldsymbol{\nabla}$ springeropen.com 